\title{
An Analytical Insight into the Information and Quality Based Management Processes at Higher Education Institutions: Liverpool John Mooress University Case Study
}

Berat Bir*, Lale Özdemir **

* M.Ü. Fen Edebyat Fakültesi Bilgi ve Belge Yönetimi Bölümü

E-mail: beratbir@marmara.edu.tr*,tulip.ozdemir@gmail.com**

Copyright (C) 2015 Berat Bir, Lale Özdemir. This is an open access article distributed under the Eurasian Academy of Sciences License, which permits unrestricted use, distribution, and reproduction in any medium, provided the original work is properly cited.

\begin{abstract}
In the Information Age in which we exist, quality management practices should be the norm rather than the exception in all higher education institutions. Quality management in universities ensures that students are attracted, additional income is secured and that the reputation of the institution is enhanced. However this success can only be achieved through effective partnerships. The aim of this study is examine Liverpool John Mooress University, UK as a case study of a higher education institution that has successfully implemented and continues to implement quality management practices within a changing international arena. Liverpool John Mooress University was the EFQM prize winner in 2008 and this study is based on field work carried out at the university witnessing first-hand the implementation of business excellence practices across the organization with particular reference to academic services. This article examines in detail the business excellence practices at Liverpool John Mooress University with a view to recommendations for implementability in Turkish universities.
\end{abstract}

Keywords: Quality, Total quality management, business excellence, EFQM

\section{Yüksek Öğrenim Kurumlarında Bilgi ve Kalite Odaklı Yönetim Süreçlerine Analitik Bir Bakış: Liverpool John Moores Üniversitesi Örneği}

\section{ÖZET}

İçinde bulunduğumuz Bilgi Çağında kalite yönetimi uygulamaları, yüksek öğrenim kurumları için de kaçınılmaz bir adımdır ve aslında, bilgi odaklılığ artık bir standart şeklinde ele alınmaktadır. $\mathrm{Bu}$ yaklaşımın bir yansıması tabii ki üniversitelerin en önemli paydaşı, kullanıcısı olan öğrencilere olacaktır zira kalite yönetimin uygulandığı bir üniversite, varoluşu, felsefesi ve gerçekleştirmek istediği hedefler açısından değerlendirildiğinde öğrenciyi cezbeder, ona iş hayatında iyi bir yer edineceği ve o hayata taşıyabileceği yetkinlik ve yeterlilikleri kazandırır. Ve genel anlamda da, ticaret-sanayi işbirliklerinin oluşturulması sonucu üniversiteye ek gelir sağlar ve kurumun itibarını artırır. $\mathrm{Bu}$ da bir üniversite için başarıdır. Ancak bu başarıya verimli paydaşlıklar kurarak erişilebilir. $\mathrm{Bu}$ çalışmanın temel amacı, İngiltere'deki Liverpool John Mooress Üniversitesi'ni, kalite yönetimi uygulamalarını başarıyla uygulayan ve değişen uluslararası arenada uygulamaya devam eden bir yüksek öğretim kurum örneği olarak analiz etmektir. Bu çalışma EFQM Modeli kapsamında, 2008 yılında, Avrupa Birliği'nin en iyi uygulamalara sahip Üniversitelerinden biri olarak, Birleşik Krallık Mükemmellik Ödülünü kazanmış John Moores 
Üniversitesi'nde gerçekleştirmiş olan saha çalışması ve özellikle alkademik hizmetler konusundaki iş mükemmeliği uygulamaları üzerine yapılmıştır. John Moores Üniversitesi'ndeki iş mükemmeliyeti ve kalite yönetim modeli çercevesindeki uygulamalar hakkında elde edilen bilgiler doğrultusunda, makalede genel bir değerlendirme yapılmaya çalışılmakta ve bu yaklaşımın, Türkiye'deki üniversitelerde uygulanabilirliği hususunda öneriler sunulmaktadır.

Anahtar Kelimeler: Kalite, toplam kalite yönetimi, iş mükemmeliği, EFQM

\section{Giriş}

Modern dönem yönetim anlayışları içinde en çok ön plana çıkan ve günümüzde de bir çok kurumun referans aldığı modellerden biri olan Toplam Kalite Yönetimi(TKY) için, aslında bir modelden çok, bir felsefe hatta kurumlar için bir kültürel yapılanma programıdır demek yanlış olmaz.. Temelinde; aileden başlamak suretiyle, toplumun tüm katmanlarında kalite anlayışını yaymak ve insanların tükettiği ürün ve hizmetten en üst seviyede tatmin ve mutlu olabilmesini sağlama anlayışı yatmaktadır.

$\mathrm{Bu}$ nedenle bu felsefeyi benimseyen kurumlar, müşteri/kullanıcı odaklı hizmet anlayışını birincil hedefleri arasına koymaktadirlar.

TKY; bir yandan müşteri ihtiyaçlarını en iyi şekilde karşılamak bir yandan da maliyetleri düşürmek suretiyle kuruluşları daha esnek ve rekabetçi kılan bir yönetim anlayışıdır. Ayrıca; uzun vadede, müşterinin tatmin olmasını, başarmayı, kendi çalışanı ve toplum için avantajlar elde etmeyi, kalite üzerine yoğunlaşmış ve tüm çalışanların katılımına dayanan bir işletme yönetim modelidir (Çetin ve diğerleri, 1998:3) Özetle, kurumun bütününde kalitedir.

Toplam Kalite Yönetiminin temel hedefi; tasarımdan servis sonrasına kadar hiç bir kişi ve birim dışarıda kalmayacak şekilde hatayı önleyerek, hata kaynaklarını ortadan kaldırma ve üretimi sürekli geliştirme yaklaşımının kuruluşun bütününde geçerli olmasına yönelik bir kurum kültürü oluşturmaktır.

21.yy, bilgi çağı, dijital çağ gibi farklı isimlerle anılırken, kurumlar açısından en dikkat çeken unsur, kurum dışı çevresel dinamiklerin sayısının artması ve bunların hızla değişmesidir. Dolayısıyla kurumların ayakta kalabilmesi, başarılı olabilmesi de, bu dinamikleri izlemeleri, bunlarla ilgili bilgi toplamaları ve gerekli değişimleri kendi iç çevrelerinde gerçekleştirebilmelerine bağlıdır. Kurumları, bu değişiklikleri yapmaya zorlayıcı unsurların en başında, onların müşteri/kullanıcıları gelmektedir; onlardan gelen talep ve beklentileri, en hızlı, en doğru şekilde karşılayabilmeleri için, diğer bir ifadeyle, onları maksimum noktada memnun ve tatmin edebilmeleri için bu kaçınılmaz bir sonuçtur. Bu nedenle, kurumların, çağın gelişen koşullarına ve dış çevrelerine uyum sağlayabilmeleri için farklı ve daha önceden bilinen, bilimselliği kanıtlanmış, uygulandığında başarılı sonuçlar yarattığına inanılan, yönetim modelleri ve tekniklerinden yararlanmaları çok akılcıl bir yoldur.

Toplam Kalite anlayışını yönetim süreçlerine yerleştirmenin en önemli nedenlerinden biri de; öğrenmeye ve değişime açık, çevredeki değişikliklere duyarlı, esnek, özetle daha rekabetçi bir kurum olabilmektir.

Bu modelin uygulanmasının kurumlara sağlayacağı öngörülen yararlar arasında;

- Ürün ve hizmet kalitesinin iyileştirilmesi.

- Kaynak israfinın azalması. 
- Müşteri tatmininin artması.

- Ürün geliştirme sürelerinin kısaltılması.

- Verimliliğin artırılması.

- Pazar talebinin karşılanmasında esnekliğin artması.

- Süreç içi işlem sayısının azalması.

- Müşteriye hizmet ve ürün teslim sürelerinin kısalması.

- İşçi ve işveren ilişkilerinin düzeltilmesi sayılabilir.

$\mathrm{Bu}$ model uygulamaya geçtiği süreden itibaren gelişme göstererek, farklı ve kapsamlı şekillerde uygulanmaya başlanmıştır. Özellikle hizmet sektöründeki işlevselliğiyle birlikte kalite standartlarının gelişim ivmesinin de arttı̆̆ gözlemlenmektedir.

$\mathrm{Bu}$ çalışmanın odak noktasını oluşturan eğitim sektörü ve yüksek öğretim kurumları temel alındığında, TKY'nin teoride ve uygulamada ne şekilde anlam kazandığına dair kısaca aşağıdaki yaklaşımları görmekteyiz;

Vollmer, "Okullar, hizmet ettiği toplumun, tutumları, inançları ve sağlıklılığını yansıtır, bu nedenle, o toplumu değiştirebilmek için, öncelikle, eğitim sistemini değiştirmekten çok, toplumu değiştirmek gerekir" derken, aslında, değişimin, önce toplumun kendisinde, bir başka deyişle, o toplumu oluşturan insanların kafasında, o toplumun kültüründe, politikalarında başlaması gereğini çargulamaya ç̧ışstır. (http://www.edweek.org/ew/ewstory.cfm?slug=25Vollmer.h21\&keywords=Total\%20Quality \%20Management, 11.03.2015)

Eğitim öğretim kurumları için değişim kaçınılmazdır zira bu kurumlar hizmet verdiği çevrelerden gelen farklı talepleri ve beklentileri karşılayabilmek için daima bilgi odaklı olmak, yenilikçi ve yaratıcı bakış açısıyla hareket etmek durumundadırlar. Bu nedenle de, kalitenin yükseltilmesi bu kurumlarda bir sorun olarak görülmüş (Küçüksüleymanoğlu, 2006: 33) ve her zaman en iyi uygulamaları referans almaya yönelik çabalar güdülmüştür.

Bu çalışmada, hizmet alanı olarak bilinen eğitim sektörü genelinden yola çıkılarak, özelde yüksek öğretim kurumlarında kalite odaklı yönetim süreçleri ele alınmış, bu alandaki başarılı uygulamalarından dolayı en iyi örneklerden biri olarak gösterilen Liverpool John Moores's Üniversitesi'ndeki ilgili süreçler araştırılarak, analitik bir çalışma ortaya konulmaya çalışılmıştır.

\section{Saha Çalışması}

Marmara Üniversitesi Kalite Birimi ve Bilgi ve Belge Yönetimi Bölümü işbirliğinde, 23-27 Haziran 2014 tarihleri arasında, Liverpool John Moores Üniversite'sine, iş süreçleri, kalite çalışmaları ve akademik ve idari birimler hakkında bilgi almak ve yerinde gözlemlemek amacıyla, bir haftalık bir araştırma gezisi gerçekleştirilmiştir.

$\mathrm{Bu}$ araştırma için John Moores Üniversitesi'nin seçilmesinin en temel nedeni; bu Üniversitenin EFQM Modeli kapsamında, 2008 yılında, Avrupa Birliği'nin en iyi 
uygulamalara sahip Üniversitelerinden biri olarak, Birleşik Krallık Mükemmellik Ödülünü kazanmış ve 2009 finalistlerinden biri olması, dolayısıyla da, kalite standartları aşamalarını geçmiş olmasıdır. Ayrıca, Üniversite, 2011 yılında da paydaşlık kurma kategorisinde ödül kazanmıştır. EFQM (European Foundation for Quality Management) 1988 yılında, Bosch, BT, Bull, Ciba-Geigy, Dassault, Electrolux, Fiat, KLM, Nestlé, Olivetti, Philips, Renault, Sulzer ve Volkswagen gibi Avrupa' nın önde gelen 14 firmasının CEO'larının imzaladıkları bir Niyet Mektubu ile hayata geçirilmiş bir vakıftır. Amacı; "Avrupa'daki kuruluşların sürdürülebilir mükemmelliğini sağlayabilmek için itici güç olmak"tır. Vakıf kuruluşunu takiben, sanayi ve akademisyenlerden oluşan bir grup ile "mükemmellik modeli" adiyla bir yönetim modeli geliştirmiştir. Model, boyutu ve sektörü ne olursa olsun tüm kuruluşlar tarafından kullanılabilen bir değerlendirme aracıdır. Model kuruluşlara, mükemmellik kavram ve kriterlerini dikkate alarak kendi değerlendirmelerini yapmalarına, güçlü ve iyileştirmeye açık alanlarını tespit etmelerine ve sürekli gelişim yaklaşımıyla gelişim planlarını hazırlamalarına yardımcı olur (http://www.kalder.org/kalderhakkinda.aspx?id=6, 11.03.2015). Ayrıca, Eğitim ve Öğretim faaliyetlerinin İngilizce dilinde gerçekleştirilmesi de bu Üniversitenin araştırma yapmak üzere seçilmesinde tercih nedeni olmuştur.

\section{Araştırma Kapsamı}

Liverpool John Mooress Üniversitesi, Kuzey İngiltere'de 1825 y1lında teknik okul olarak kurulmuş ve 1992 yılında üniversite statüsü kazanmıştır. Liverpool John Mooress Üniversitesi; İngiltere'nin Liverpool şehirinde çeşitli kampüsleri, 250 lisans programı, 3,000 personel ve 25,000 öğrencisi olan bir kurumdur. Liverpool John Mooress Üniversitesi'nin dünya görüşü ve değerleri, 21.yy’ın üniversitenin karşı karşıya kaldığı çevresel zorluklar ve risklerle yüzleşmek ve adapte olmak üzere geliştirilmiştir http://www.ljmu.ac.uk/AboutUs_City/index.htm, 19.02.2015).

Üniversitenin 2012-17 Stratejik Planında yer alan vizyonuna göre; Üniversite, 21.yy'ın getirdiği sorunlara çözüm getirmek ve halkla içiçe olan bir modern üniversite olarak tanınmaktır (http://www.ljmu.ac.uk/Vice Chancellor/Docs/ljmu strategy 2012-2017.pdf, 19.02.2015).

Üniversite personeli Liverpool şehrinin çeşitli okul, vakıf ve sanat gruplarında ve komitelerinde aktif rol almaktadır.Bu bağlamda, bir buçuk yıl boyunca Üniversitede aktif çalışanlardan oluşan gönüllü platformu, Age Concern ve DaDaFest de dahil olmak üzere dört tane hayırsever surumuna destek sağlayacaktır (http://www.ljmu.ac.uk/AboutUs_City/index.htm, 19.02.2015).

Üniversitenin stratejik planı; statükonun devam ettirilmesinin bir seçenek olmadığını ve esas sorunun, şu anda ülke ekonomisinin ortaya koyduğu zorluklarla mücadele etmek ve yeni mezunların istihdam sorunlarını çözebilmek için yeni yaklaşımlar geliştirmesinin şart olduğunu vurgulamaktadır.

Üniversitenin öğrencilerinin \%92'si mezun olduktan yaklaşık altı ay sonra ya istihdam olmakta ya da lisansüstü eğitime devam etmektedir (http://www.ljmu.ac.uk/AboutUs_City/index.htm, 19.02.2015).

Üniversite, özel geliştirdiği "Dünya İş Dünyası" (World of Work) programıyla, Londra Borsa'sında yer alan 100 şirket ile iş birliği yaparak, öğrencilerin mezun olunca hayallerindeki işi yapabilmeleri ya da kendi işlerini kurmaya yönelik onlara yetenekler

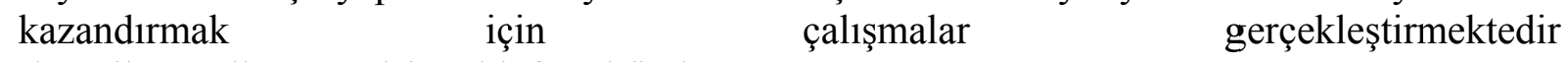
(http://www.ljmu.ac.uk/worldofwork/index.asp, 19.02.2015).

Liverpool John Mooress Üniversitesi ayrıca Eşitlik ve Farklılık (Equality and Diversity) 
ilkelerine bağlı bir kurumdur ve bunun göstergesi olarak, Stonewall's Top 100 de yer alan işverenler tarafından "eşcinsellere en açık iş yeri" olarak seçilmiştir. Aynı zamanda EFQM dışında, engelliler platformları ve insan kaynakları alanlarında da başarı göstermektedir.

Önceden belirlenmiş olan iş planı aşağıdaki gibi olmuştur;

- 23 Haziran 2014 tarihinde; Strateji Yönetim Birimi’yle 4 saatlik bir tanıtım ve bilgilendirme toplantısı yapılmıştır.

- 24 Haziran 2014 tarihinde; John Moores Üniversitesi Üniversite/İşveren Ortaklığını Geliştirme ve Destekleme Araştırması na yönelik, Dünya İş Kariyer Merkezi(World of Work Career Centre)'yle 7 saatlik görüşme ve bilgilendirme eğitimi

- 25 Haziran 2014 tarihinde; İş Yönetimi Birimiyle, "Farklılık ve Eşitlik" konularında 7 saatlik bir görüşme ve bilgilendirme toplantısı yapılmıştır.

- 26 Haziran 2014 tarihinde; Öğrenme, Öğretim ve Değerlendirme Birimi’yle, , özellikle akademik personelin mesleki standartları, geliştirilmesi konularında bilgillendirme toplantısı gerçekleştirilmiştir.

\section{Araştırmanın Amacı}

$\mathrm{Bu}$ araştırma çalışmasının temel amac1; Avrupa Mükemmellik Ödülünü almış bir Avrupa Birliği Üniversitesinin, üniversite altyapısı ve iş süreçleri, değişim yönetimi ve iş mükemmellik modelleri hakkında, bizzat yerinde gözlem yaparak, yetkili kişilerle yüz yüze görüşmeler yapmak ve seminer ve eğitim programlarına katılarak, bilgi toplamak ve sonrasında, bu yapılan değişim uygulamalarının, genelde bir yüksek öğrenim kurumuna ve özelde ise, Marmara Üniversitesi kapsamında uygulanabilirliğinin ortaya konulmasıdır. Özellikle iş süreçlerinin altyapısının iyileştirilmesi, performans geliştirme açılarından, doğru uygulamaların modellenmesi açısından bu inceleme çalışmasının yararlı olacağ öngörülmüştür. Aynı zamanda, iki kurum arasında bilgi paylaşımı, bilgi dönüşümünün sağlanması ve ileriye yönelik işbirliği olasılıklarının ortaya konulması açısından da, söz konusu çalışmanın ikincil amaçlara hizmet edeceği varsayımından da yola çıkılmıştır.

\section{Araştırma Yöntemi}

Araştırma için, Liverpool John Moores Üniversite'ne bir haftalık araştırma yapmak üzere gidilmiştir. İdari ve Akademik olmak üzere, farklı birimlerin yetkili kişileriyle yüz yüze görüşmeler yapılmıştır. Aynı zamanda bizlere; bu birimlerin işleyişi, iş süreçleri, kalite çalışmaları ve iyileştirme faaliyetleri hakkında önceden planlandığı üzere eğitimler verilmiştir. Görüşme yapılan birimler;

- İş Mükemmelliği Birimi (Business Excellence)

- Kariyer Geliştirme ve İstihdam Merkezi (Career Development and Employbility)

- Araştırma ve Geliştirme (Research and Development)

- Insan Kaynakları Birimi (Human Resources Unit)

- Eğitim ve Akademik Kalite Hizmetleri Birimi (Education and Academic Quality Services Unit)

- Akademik Personel İşleri Birimi (Academic Registery Unit)dir.

$\mathrm{Bu}$ çalışma nitel bir çalışmadır. Öte yandan, birimler tarafından bize verilen eğitimler doğrultusunda ve elde edilen veri ve bilgiye yönelik olarak, bir analiz çalışması gerçekleştirilmiştir. 


\section{Araştırma Bulguları}

\section{$>$ İş Mükemmelliği Birimi:}

Yapılan görüşmelerde vurgulanan temel nokta; üniversitenin genelinde yönetim sürecinin etkinliği ve mükemmelliği açısından önemli olan unsurun, süreçlerin verimliliğinden önce, akademik personelin tutum ve davranışları olduğudur. Bir başka ifadeyle, Üniversitenin kalite imajını belirleyecek olan önceliğin, akademik personelin tutum ve davranışları ve özellikle de öğrenci odaklı yaklaşımlarının varlığıdır.

Üzerinde durulan ikinci nokta; EFQM modelinin, Üniversite'ye entegrasyonunun önemli olmasıdır. Üniversite modele uyum sağlamak için değil, modelin Üniversiteye uyum sağlaması için eyleme geçilmesi önemlidir.

EFQM modelinin genel olarak Üniversiteye uyarlanmasında;

- Üniversitenin hedef/amaç, misyon ve vizyonunun ne olduğu,

- Stratejilerinin neler olduğu,

- Stratejileri gerçekleştirmek ve hedeflere ulaşmak için en uygun liderlik modelinin hangisi olduğunun belirlenmesi önemli kriterler olarak vurgulanmıştır.

Kaliteli bir yönetim anlayışı açısından üzerinde durulması gereken önemli unsurlardan birinin de; bir üniversite için üretilen ürünün, hizmet olduğu unsurunun unutulmaması gereğinin altı çizilmiştir. Eğitim ve öğretim faaliyetlerini geliştirmek ve iyileştirmek, bir üniversite için ürün niteliği taşımaktadır. Bunu yapmak için, iş süreçlerinin yeniden gözden geçirilmesi ve stratejilerin uygun hale dönüştürülmesi gerekir.

\section{Kariyer Geliştirme ve İstihdam Birimi}

Yapılan görüşmelerde vurgulanan en önemli nokta; verilen eğitimin ve öğretim faaliyetlerinin öğrencilerin iş hayatına yönelik ve istihdamları konusunda firsat yaratabilme özelliğine sahip olmasidir.

Üniversite müfredatının içeriğinin oluşturulmasında en önemli kriterlerden biri; iş hayatıyla paralellik göstermesi, güncel bilgi ve uygulamaları içermesi ve iş olanaklarının sağlanmasına yönelik hale getirilmesidir.

Yukarıda belirtilen kriterler doğrultusunda, öğrencilerin öğrenim hayatları süresince yapmaları gereken stajlar iki türlüdür; zorunlu ve parasız olan ve istenildiği taktirde, seçmeli ve paralı olanlardır.

Yine bu görüşmelerde özellikle altı çizilen nokta; üniversitelerin bir işletme olduğu ve dolayısıyla da bir işletme mantığıyla hareket etmesi gereğidir. Bu bağlamda, üniversitelerin öğrencilere sadece bilgi aktarması, onları eğitmesi ve öğrenim faaliyetlerinin mevcudiyeti, bir üniversite olmak için yeterli görülmemelidir. Bunun için gerekli altyapı, üniversite müfredatının, öğrencilerin gerekli rol, beceri ve yetkinliklerini geliştirme konusunda, onlara yol gösterici olmak durumuna dönüştürülmedir. Bu durum, ancak, gerek idari personelin politika ve stratejileri şekillendirmesi, gerekse, akademik personelin bu yapılanmaya fiili olarak destek sağlamasıyla gerçekleşecektir. Bundan dolayı üniversitelerin sanayi, ticaret işbirliğini önemsemesi ve iş dünyasıyla devamlı iletişim halinde olarak, müfredatın belirlenmesinde onların görüşlerine yer vermesi gerekmektedir.

Merkez, çok bilinen, "Kariyer İçin Yapılacaklar Rehberi” hazırlamıştır. Bu rehberin, 2017 yılı itibarıyla 5000 öğrenciye ulaşacağı öngörülmektedir. 
- Strateji Birimi'ne, Kariyer Rehberlik hizmetleri kapsamında, kariyer hedeflerine yönelik ölçütler gönderilmiştir.

- Seçtikleri lisans alanlarıyla ilgili olarak, 5500 üstünde mezun öğrenciyle iletişime geçilmiştir.

- Başarı kiriteri için anahtar; stratejik yönetim anlayışıdır.

- Güçlü bir istihdam istatistik veritabanının varlığı, Üniversitenin ulusal seviyedeki yerini etkilemesine yardım etmektedir.

\section{Araştırma ve Geliştirme Birimi}

Yapılan görüşmelerde, sıkılıkla vurgulanan husus; Birleşik Krallık genelinde Üniversitelerin araştırma odaklı ve eğitim- öğretim odaklı olmak üzere iki farklı türde faaliyet gösterdikleridir. Öte yandan her üniversitede araştırma faaliyetleri, akademik personelin görevlerinin bir parçasıdır. Ancak, iş öncelikleri hedefler doğrultusunda belirlenmektedir. $\mathrm{Bu}$ bağlamda; gerek eğitim ve öğretim kalitesinin arttırılması, gerekse akademik performansın geliştirilmesi açısından, araştırma yapmanın ve bilginin akademik ve idari personel kapsamında paylaşılması/ transferinin önemi vurgulanmıştır.

Kurumun stratejilerinin hayata geçirilmesi açısından, araştırma ve inovasyon faaliyetleri çok önemlidir. Ancak son yıllarda hedeflerin degişmesiyle birlikte, araştırmanın ticari faydaları göz önünde bulundurularak, özellikle kamuyu ilgilendiren ve kamuya faydalı olacak araştırmaların ön plana çıkartılması teşvik edilmektedir.

Araştırma faaliyetleri konusunda, Üniversitenin genel politikası; akademik personelle ilgili beklentilerin gerçekçi olması yönündedir. Bu olgu özellikle uygulamacı olanlar (tıp alanında mesela) ve sahada çalışan akademisyenler için çok daha fazla geçerlidir. Nitekim Üniversitenin İşlevsel Stratejik Planı (Operational Strategic Plan) araştırma konusundaki beklentileri net bir şekilde ortaya koymaktadır.

Akademik personel için araştırma yapmak onların kariyer ve terfileri açısından önemli olmakla birlikte, ulusal çapta bir farkındalığın yaratılmasının ölçülmesi de öncelikli bir kriter olarak vurgulanmıştır (benchmarking). Bu bağlamda, yapılan araştırmalara maddi destek verilerek akademisyenler teşvik edilmektedir.

Üniversitede yapılan bilimsel araştırmalar, sonucta kurumun profili açısından önem teşkil etmektedir zira, Yıllık Ulusal Lig Tablosunda üst sıralarda yer almak, başarılı üniversiteler içinde sayılmak, doğal olarak üniversiteler için önemlidir.

Bunların yanısıra, uluslararası arastirmalarin öneminden de söz edildi. Buna göre; Liverpool John Moores's Üniversitesi'nde yapılması gereken araştırmaların kalite ölçeklerinin aşağıdaki şekilde olması gerektiği vurgulandı;

- 2014-2020 y1lları arasında, her bir akademisyenden en az dört yayın yapmas1 istenilmektedir.

- Akademik personelin terfi etmesi otomatik olarak uygulanmamaktadır. Bu nedenle de, belli bir kıdeme sahip olmak, akademisyenin terfi ettirilmesi için, bir "hak" olarak görülmemektedir.

- Üniversitede, ögretim görevlisi, kıdemli öğretim görevlisi, kıdemli akademisyen(bizdeki doçentliğe karşılık gelmektedir) ve profesör olmak üzere, ünvanlar dört farklı şekilde 
isimlendirilmektedir;

- Terfi icin dört temel kriter vardır;

- Araştırma ve yayın yapmak,

- Akademik liderlik ( alanında örnek akademisyen olmak)

- Öğrenim mükemmeliyeti ( ders vermek, öğrencilere bilgi ve tecrübesiyle destek olmak vb. konularda)

- İdari ve öğrenci işlerinde, kurumun farklı düzeylerinde katılım

- Terfi jurileri dört bağımsız üyeden ibarettir. Başvurular ilgili merkeze gönderildikten sonra, değerlendirme sürecine alınır. Karar verme sürecinde baska bir üniversitenin rektör yardımcısının da rolü olur. Değerlendirme aşamasında, adayın yayınlarımın yanısıra ragmen adayın cok iyi bir şekilde öğretmen olması ve dersleri başarıyla yürütebilmesi ön planda bulundurulur. Burada altı çizilmesi gereken önemli nokta; derse girmek istemeyen ve öğrencilerle ilgilenmek istemeyen akademisyenlerin terfi başvurularının red edildiğidir.

- Yayınların müfredata katkı sağlaması ve müfredatta yer aldığını ispatlaması şartıyla, üniversite politikaları kapsamında, başarı ödüllendirilmektedir. Buna göre; yılda 10-11 milyon pound toplam araştırma bursu verilmektedir.

- Yayınlar konusunda, yayın sayısından ziyade, bu yayınların kalitesinin önemi vurgulanmıştır.

- Özellikle doktora öğrencileri araştırma yapmak için önemli bir kaynaktır (araştırmacı olarak). Mevcut rakamlar, üniversitenin 500 doktora öğrencisi olduğunu göstermektedir.

\section{İnsan Kaynakları Birimi:}

Üniversitede insan kaynakları faaliyetleri insan kaynakları ve insan kaynakları programları olmak üzere, ikiye ayrılır. Üniversite İnsan Kaynakları Programları Birimi iş verenlerle yakın irtibatta çalışmaktadır.

Öğrenciler öğrenim hayatları boyunca, akreditasyonlu programlara katılıp, mezun olmadan önce, belli mesleklerde akreditasyon kazanma hakkına sahiptir. Bir öğrencinin akreditasyon kazanmadan mezun olması çok nadiren görülmektedir.

Üniversitenin stratejisi açısından, özellikle önem verdiği konulardan biri de; öğrenci ve iş verenleri bir araya getirerek, öğrencilerin, iş hayatından beklentileri konusunda seminerler düzenleyerek, onları iş hayatına hazırlamaya aracı olmaktır.

Öğrenciler öğrenim hayatları süresince, iki tür staj yapmak durumundadır; müfredatta yer alan akreditasyonlu staj programı; üç yıl devam eden stajlar (maaşsı) ya da dört yıl devam eden (maaş11)stajlardan oluşmaktadır. Bu stajların temel amacı, öğrencilerinı transfer edilebilir nitelikler kazanması ve profesyonel beceriler edinerek, iş hayatına adapte olup çalışabilmelerine olanak tanımasıdır. Bu bağlamda Üniversite-Sanayi-Ticaret işbirliği çok önemsenmektedir. Örneğin; Liverpool Havaalanı stajyer kabul eden en yeni iş verenlerden biri olarak örnek verilebilir.

Üniversite müfredat1, ögrencinin her hangi bir bölümde okurken, İnsan Kaynakları Bölümünde ÇAP ya da Yandal yapabilmesine imkan tanımaktadır. Öğrencilerin, akreditasyon kazanabilmek için üç senelik maaşsız staj yapma konusunda oldukça talepkar olmaları da dikkat çekici bir noktadır.

Üniversitede kalite kontrol süreci önemli bir süreç olarak öne çıkmaktadır: Üniversite, 
Chartered Institute of Personal Development gibi akreditasyon veren kurumlarla çalışmaktadır. Adı geçen bu bağımsız akreditasyon kurumu, özgun ve uzaktan, bir karışık değerlendirme yöntemi kullanmaktadır. (blended learning).Üniversitenin iç kalite kontrol süreçleri, akreditasyon veren birimlerle paralel bir şekilde çalışmaktadır.

Üniversite, 2014 yılında, İngiiliz The Guardian gazetesi tarafından üniversitelere verilen ödüllerde Uluslararası Proje kategorisinde , "Küresel Kariyer Geliştirme Ortaklığı" konusuyla eleme listesine girmeyi başarmıştır (http://www.theguardian.com/higher-educationnetwork/2013/dec/11/guardian-university-awards-2014-shortlist, 11.03.2015).

Genel İnsan Kaynakları'na gelince ise;

Üniversitenin "Respect” sloganı altında çok geniş çaplı bir kampanyası vardır. Her bir öğrenci ve personelin sayg1 kavramı çerçevesi içerisinde kurumsal vatandaş olması teşvik edilmektedir.

Her fakültede eşitlik konularını tartışan iki tane forumu mevcuttur. Bu forumlarda ele alınan güncel konular arasında en başta, eşitlik adı altında (İngiltere'de 2010 yılından beri Eşitlik Yasas1 yürürlükte):

- Öğrenci beklentileri

- Personel beklentileri

- Öğrenim ve müfredatta eşitlik kavramının yeri

- Öğrenciler icin eşit fırsatlar başlıkları vardır.

Üniversitenin kurum kültüründe, farklılıkları kabul edip kucaklama değeri hakimdir. Bu nedenle, Üniversitenin bu konulardaki politika ve prosedürleri sık sık gözden geçirilmekte ve öğrencilere saygı kavramını içine alan Code of Practice (Etik Anayasası) uygulanmaktadır (http://www.ljmu.ac.uk/corporate/120795.htm, 19.02.2015). Ayrıca üniversiteye yeni giren personel icin verilen egitimlerde de saygı kavramının önemi üzerinde durulmaktadır. Son yılların çok bilinen kavramlarından olan; taciz (mobbing), ırkçılık ve cinsel ayırımcılık için "Zero Tolerance"adıyla bilinen bir kampanya vardır. Bu kampanyaların kurumsal başarıya ulaşabilmesi ve zihinsel farkl1lık yaratabilmesi için, üniversite üst düzey yöneticilerinin de bu yaklaşımı önemsemesi gerekir. Bunun için; bir dekanın eşitlik konusunda gösterdiği yaklaşımlardan dolayı şampiyon olabilmesi ve çalışma grubunun başkanlığını yapabilmesi gibi uygulamalar gerçekleştirelebiliyor. Bu tutumuyla da yöneticiler arasında rol model haline gelebiliyor.

Tüm bunların yanısıra, mobbing ve mobbing'in yarattı̆ğ etkiler üzerinde büyük çapta kampanyalar yürütülmektedir. Bununla ilgili performans hedefleri şekillendirilmekte ve uygulamalarla ilgili iyileştirme çabaları gerçekleştirilmektedir Hatta üniversitede, herkese destek olmak üzere, taciz danışmanları görev almıştır (Harrassment advisers). (https://www.ljmu.ac.uk/ /media/files/ljmu/public-information-documents/equality-anddiversity/bullying-and-harassment-policy.pdf?la=en, 15.04.2015)

\section{Egitim ve Akademik Kalite Hizmetleri Birimi:}

$\mathrm{Bu}$ birimin misyonu temelde; ünüversitenin eğitim kalitesini yükseltmek ve özellikle de akademisyenlerin performansını iyileştirmeye yönelik çalışmalar gerçekleştirmektir.

Bu birimle yapılan görüşmelerde öncelikle belirtilen en önemli konu; tüm üniversite akademik personelinin ünvanı ne olursa olsun atandığı zaman "profesyonel tanınırlık" adında 
profesyonel bir sertifika programına katılıp, bu programı başarıyla bitirmesi zorunluluğunun olmasıdır. Bu uygulama ulusal alanda zorunlu değil ama LJM Üniversitesi, standartları yüksek tutmak adına bu uygulamayı yürürlülüğe koymuştur.

Akademik personel atamaları, onların yaptıkları araştırmalar göz önünde bulundurularak yapılır. Ayrıca eğitim öğretim faaliyetlerine katılımları(derse grime, v.b.)ve deneyimleri de değerlendirmeye alınır. Eğer akademik personelin bu anlamda eksiklikleri varsa, atanabilmeleri için farklı bir eğitim programına katılmak zorunluluğu vardır; personel; hem işini yapıp, hem de bu programa katılmak durumundadır (PCert).

Ayrıca her profesyonel kurumda olması gerektiği gibi, Liverpool John Mooress Üniversite'sinde de, personelin performansı değerlendirilir. Munde'e göre genelde performans değerlendirme süreci hem şefler hem personel tarafından hoş karşılanmamaktadır (Munde, 2013:101). Performans değerlendirmesi oldukça zor ve objektif yapılması gereken bir süreçtir. $\mathrm{Bu}$ nedenle, bu değerleme işlevinin, modern yönetim tekniklerinden ve standartlarından yararlanılarak yapılması, daha doğru kararlar alınması, verimli bir çıktı elde edilmesi ve özellikle de personelin geliştirmesi açısından önemlidir.

Öğretim deneyimi olan personel, yukarıda sözü edilen "professional recognition" programına katılırken, yeni atanan akademik personel terfi ve atamalarda, derste gösterdikleri performans üzerinden de değerlendirmeye alınırlar. Zira, ders esnasında, en az üç dört kere gözlemlenirler, ayrıca öğrenciler vasıtasıyla, ulusal öğrenci anketi kullanılarak alınan geribildirimler de değerlendirmeye veri teşkil eder.

\section{Akademik İşler Birimi:}

Bu birimin idari sorumlulukları arasında;

- $\quad$ Öğrenci desteği sağlamak,

- $\quad$ Öğrenci işleri,

- $\quad$ Akademik planlama olmak üzere üç temel alanda akademik kaliteyi yükseltme hedefi vardır.

- $\quad$ Bunun yanısıra; Kalite Anayasası'nın ve yukarıdaki tüm idari fonksiyonlarla ilgili olan politika ve prosedürlerin uygulanmasını sağlar.

Bağımsız Yargı Ofisi, akademik anlamda bir denetleme mekanizmasıdır. (Office of Independent Judicator) bu birim, kalitenin arttırılması için neler yapılması gerektiği üzerine çalışmalar yapar.

Yapılan görüşmelerde özellikle paydaşların üniversite için önemli olduğu ve onların da taktir edilmesi gereği vurgulanmıştır.

Ayrıca, Öğrenci Temsilci Komiteleri oluşturularak, müfredatın geliştirilmesi ile ilgili öğrencilerin fikirlerini almak üzere toplantılar düzenlenmektedir. Yine bu amaçla, “Öğrencinin Sesi Haftası" (Student Voice Week) gibi uygulamalarla, akademik personel hakkında onlardan geribildirimler alınır. Öğretim kalitesinin arttırılması konusunda yine örnek uygulamalardan biri de; öğrenci sınav kağıtlarının dışarıdan atanan değerlendiriciler vasıtasıyla belli bir ölçüde ve belli zamanlarda değerlendirmeye alınmasıdır.

\section{Sonuç ve Değerlendirme}

Bir Üniversitenin başarılı ve verimli bir yönetim anlayışına sahip olabilmesi son derecede önemlidir. Bu anlayış öncelikle yönetici ve yönetim süreciyle başlamalı ve kurumun tüm paydaşlarına yansımalıdır. Çağdaş ve profesyonel kurumlar için değişim, dönüşüm ve gelişim 
kaçınılmaz bir olgudur. Bu bağlamda yaptığı işi doğru yapmak isteyen, hedef ve amaçlarına doğru zamanda ulaşmak isteyen, rekabet üstünlüğü sağlayarak, pazarda lider olmak isteyen her kurum modern yönetim modelleri ve uygulamalarından yararlanır ve bu modelleri kendisine referans alır.

Toplam Kalite Yönetimi, İş Mükemmelliği gibi yönetim anlayışları, birçok gelişmiş ülkede, profesyonel kurumlar tarafından örnek alınmaktadır. Bunların arasında üniversiteler de vardır.

$\mathrm{Bu}$ çalışmada inceleme konusu olan Liverpool John Moores Üniversitesindeki modern yönetim uygulamaları hakkında elde edilen bilgiler ışığında, şu sonuçlara varılmıştır;

- Üniversitede mükemmellik anlayışının yerleştirilmesinde en temel nokta; akademik personelin tutum ve davranışlarının öğrenci odaklı olması gereğidir. Bunun için, A'dan Z'ye tüm süreçlerin ve tüm Üniversite idari ve akademik personelinin sundukları hizmette öğrenci merkezli yaklaşımları benimsemeleri gerekmektedir.

- Toplam kalite odaklı bir üniversitede, liderlerin ve yöneticilerin, öğrenci odaklı bir anlayışı kurum kültürüne yerleştirmek ve yaymak gibi bir misyonu vardır. Onların desteği, rol model olmaları ve yönlendirmeleri çok önemlidir.

- $\quad$ İş süreçlerinin etkinliği önemlidir ve bunun için, EFQM modeli referans alınmalıdır. $\mathrm{Bu}$ bağlamda stratejik yönetim yaklaşımının uygulanması etkilidir. Özellikle kısa, orta ve uzun vadeli hedeflerin belirlenmesi ve bu hedeflere ulaşılıp ulaşılmadığıyla ilgili mutlaka performans değerleme uygulamasının devreye konulması gerekmektedir.

- $\quad$ Kaliteli bir yönetim anlayışı açısından üzerinde durulması gereken önemli unsurlardan birinin de; bir üniversite için üretilen ürünün, hizmet olduğu unsurunun unutulmaması gereğinin altı çizilmiştir. Eğitim ve öğretim faaliyetlerini geliştirmek ve iyileştirmek, bir üniversite için ürün niteliği taşımaktadır.

- $\quad$ Bir üniversite için, misyon tabii ki öğrencilere bilgi aktarmak, onları eğitmek ve öğrenim faaliyetlerini gerçekleştirmektir ama bu temel amaçlar bir üniversite olmak için yeterli görülmemelidir. Onları hayata hazırlama, özellikle de iş dünyasının ihtiyaç ve beklentilerine cevap verebilme konusunda onlara gerekli yeterlilikleri kazandırmaya yönelik müfredat ve uygulamalara yer verilmesi gerekmektedir. $\mathrm{Bu}$ durum, ancak, gerek idari personelin politika ve stratejileri şekillendirmesi, gerekse, akademik personelin bu yapılanmaya fiili olarak destek sağlamasıylla gerçekleşecektir.

- Başarılı üniversitelerde özellikle akademik personelin hem idari, hem de akademik çalışma yapması ordaki misyonlarının başında ge:lmektedir. Önemli noktalardan biri; birey başına akademik performans beklentilerinin çok iyi analiz edilerek, gerçek hedef ve kriterler oluşturulması önemlidir. Ayrıca, akdemik çalışmaların ve akademik personelin paydaşlarıyla ve öğrencileriyle bilgi paylaşımına önem vermeleri de performans değerlendirme kapsamına alınmalıdır. Bu durum, üniversiteleri, hem tercih edilir hale getirecek, hem, saygınlıkları artacak, hem de, ülkenin gelişmişlik düzeyine katkı sağlayacaktır. Söz konusu Üniversitede de, akademik çalışmalar, milli katma değer yaratacak bir unsur olarak görülmekte ve bu nedenle de üst yönetim tarafindan maddi ve manevi olarak desteklenmektedir. Nitekim EFQM Modeli'nde belirtilen dinamikler arasında en önemli olanlarından biri; kurumların paydaşlarını, topluma değer yaratacak faaliyetlere katılmaları konusunda cesaretlendirilmeleri ifade edilmiştir http://www.kalder.org/uploads/modeltanitimkitabi.2015.pdf, s.5,08.05.2015

- $\quad$ Öğrencilerin iş hayatına yönelik staj yapmaları, kalite odaklı bir üniversite için 
son derecede önemlidir. Aynı zamanda akreditasyon faaliyetlerinin gerek üniversite iç süreçleri, gerekse diş çevre açısından değerlendirilmesine önem verilmektedir.

- $\quad$ Üniversitelerde, stajların, Üniversite-Sanayi-Ticaret işbirliğini sağlamaya araç olması açısından çok önemli bir süreç olduğu göz önünde bulundurulmalıdır. Ve bu stajların temel amacı, öğrencilerin iş hayatıyla paralel nitelikte yeterlilik kazanması ve profesyonel beceriler edinerek, iş hayatına adapte olup çalışabilmelerine olanak tanımasıdır.

- $\quad$ Üniversitelerin kurum kültürü özellikle demokrasi, insan hakları, farklılıklara sayg1, taciz (mobbing), ırkçılık ve cinsel ayırımcılık gibi olumsuz tutum ve davranışları dışlayan ve hatta cezalandıran uygulama ve evrensel değerleri kapsamak zorundadır. Nitekim bu durum kalite ve bilgi odaklı yönetim modelleriyle de desteklenmektedir. Birçok profesyonel kurumda da var olduğu üzere, üniversitelerde de, etik değerlere önem verilmesi ve bu bağlamda bir Etik Anayasası (Code of Practice) uygulanması kaçınılmazdır.

- Üniversitelerde, akademik kalitenin yükseltilmesine yönelik öğrencilerin, hocaların ve idari personelin fikir ve önerilerinden yararlanılmasına yönelik politikaların uygulanmasına öncelik verilmelidir. Bu bağlamda, yönetim tarafından, tüm paydaşların özgürce paylaşımda bulunabilecekleri platformlara destek verilmeli ve geribildirim mekanizmaları işlevsel hale getirilmelidir.

- $\quad$ Son olarak vurgulanması gereken en önemli nokta; bir üniversitede, tüm yukarıda ifade edilen uygulama ve yaklaşımların, hayata geçirilebilmesi için, bir zihniyet değişimine, farkındalığı yüksek bir liderlik anlayışına, bilginin etkin yönetilmesi gereğine, sürekli öğrenme ve gelişme odaklı olmaya ve iş mükemmellik modelleri ve toplam kalite modeli ve felsefesinin öne çıkardığı kullanıcı/müşteri odaklı olmaya gereksinim vardır.

\section{REFERENCES}

- Erol, V., Akın, B., \& Çetin, C. (1998). Toplam Kalite Yönetimi ve ISO 9000 Güvence Sistemi. İstanbul: Beta Yayınları.

- Küçüksüleymanoğlu, R. (2006). Eğitim Örgütlerinde Stratejik Planlama ve Kalite İlişkisi. Çağdaş Eğitim Dergisi(334).

- Munde, G. (2013). Everyday HR. ???: ISBN-13: 978-1555707989 American Library Association.

- University, L. J. (May, 2013). Staff Bullying \& Harassment Policy. Liverpool: Liverpool John Mooress University.

\section{INTERNET REFERENCES}

- The Guardian. (2015.03.11). Guardian University Awards 2014 Shortlist Announced. http://www.theguardian.com/higher-education-network/2013/dec/11/guardianuniversity-awards-2014-shortlist

- KALDER Türkiye Kalite Derneği. (2015). EFQM Mükemmellik Modeli Tanıtım Kitapçığı. KALDER: http://www.kalder.org/uploads/modeltanitimkitabi.2015.pdf

- KALDER Türkiye Kalite Derneği. (2015.03.11). EFQM Mükemmellik Modeli. KALDER: http://www.kalder.org/kalderhakkinda.aspx?id=6 
- Liverpool John Mooress University. (2015.02.19). About LJMU. LJMU: http://www.ljmu.ac.uk/AboutUs_City/index.htm

- Liverpool John Mooress University. (2015.02.19). Code of Conduct for Staff. LJMU: http://www.ljmu.ac.uk/corporate/120795.htm

- Liverpool John Mooress University. (2015.02.19). Embracing the challenges of the 21st-century. LJMU: http://www.ljmu.ac.uk/AboutUs_City/index.htm

- Liverpool John Mooress University. (2015.02.19). A modern civic university. LJMU: http://www.ljmu.ac.uk/AboutUs_City/index.htm

- Liverpool John Mooress University. (2015.02.19). Strategic Map 2012-17. LJMU: http://www.ljmu.ac.uk/Vice_Chancellor/Docs/ljmu_strategy_2012-2017.pdf

- Liverpool John Mooress University. (2015.02.19). World of Work Careers Centre. LJMU: http://www.ljmu.ac.uk/worldofwork/index.asp

- Liverpool John Mooress University. (2015.02.19). Staff Bullying and Harrasment Policy 2013-2016

- https://www.ljmu.ac.uk/ /media/files/ljmu/public-information-documents/equalityand-diversity/bullying-and-harassment-policy.pdf?la=en, 15.04.2015)

- Vollmerr, J., R. (2015.03.11). Total Quality Management. Vollmerr: http://www.edweek.org/ew/ewstory.cfm?slug=25Vollmer.h21\&key/words=Total\%20Q uality\%20Management 